would, he presumes, associate it with those birds. "Like many other of these antipodean forms, it must be regarded as an anomaly; it is, in fact, a Biziura, and nothing more, for it stands alone."

The Musk-duck has a lengthened, stiff, and leather-like appendage banging from the under surface of the bill, and is the only member of the family which possesses this singular structure. Its lengthened tail, composed of twenty-four narrowed and stiffened feathers, is, no doubt, most serviceable to it in swimming and diving. The female does not carry the chin-lobe, and is very much smaller than the male bird.

The Musk-duck is widely distributed on the Australian Continent, and also inhabits 'Tasmania. As Mr. Gould tells us, it frequents the bays and inlets of the sea, the upper parts of rivers, lakes, and secluded pools. "More than a pair are rarely seen at one time ; often a solitary individual takes up its abode in some favourite pool, where it lives a life of complete seclusion, depending for its food and for its preservation from danger upon its powers of diving rather than upon those of flying. It is very difficult to shoot, as it dives instantly a gun is fired, so that the shot has hardly time to reach it.

The male examples of this curious duck were purchased by the Zoological Society on February 8 last. They were not in good condition when received, and though the utmost care was taken of them, one of them is since dead. The other may be seen in one of the tanks at the end of the Fish-house.

\section{THE LIFE-HISTORY OF THE EEL}

$A$ LL persons interested in the mystery that until quite A recently hung over the life-history of the eel, will find themselves under great obligations to W. Brown Goode for the very able and exhaustive account which he has quite recently published on this subject in the Bulletin of the United States Fish Commission, based upon the scholarly work of Jacoby, and from which we abstract the following. The number of species described by some authors is very large. Dr. Günther would seem to recognise only about twenty-five. Dareste still further reduces the number, making but four species in the genus Anguilla. $A$. vulgaris, occurring throughout the northern hemisphere in the New and in the Old World, $A$. mowa and $A$. marmorata in the Indian Ocean, and $A$. megalostoma in Oceania, and he further declares that even between these four the boundaries are not clearly defined. The habits of the eel are still not quite understood. So far as is known, it is the only fish, the young of which ascend from the sea to attain an imperfect maturity, and return to the sea to deposit their spawn. The economical value of the eel as a food fisb has been now well established, and they easily admit of being artificially introduced into lakes and rivers. The reproduction of the eel has from the days of Aristotle given rise to the most wonderful conjectures and assertions. Leaving out of question such old theories as that the eels are generated from dew, slime, horsehair, and from the skins of old eels, it has been a matter of dispute for centuries whether the eel is an oviparous or a viviparous animal. The reproduction of the eel was a mystery to the learned Greeks. While they knew that other fishes deposited their eggs, no discovery of the eggs of eels was ever made by them. The Greek poets solved the mystery in an off-handed way; for as they were in the habit of assigning to Jupiter the paternity of all children not claimed by earthly fathers, so they attributed the progenitorship of the eels to the same Jove.

With the revival of the study of the natural sciences in the sixteenth century, we find that investigators turned their attention with great ardour to this special subject, and such renowned investigators as Aldrovandi, Rondelet, and Salviani published elaborate treatises on the genera- tion of the eel; and they were followed by Albertus Magnus, Leuwenhoek, Elsner, Redi, and. Fahlberg.

It was in the eighteenth century that for the first time the roe of the female eel was discovered. A surgeon of Comacchio, named Sancassini, in 1707, sent the ovaries, as he thought, of an eel, to the celebrated naturalist Valisneri, who sent an account thereof to the Academy of Bologna. Prof. Valsalva appears to have doubted the correctness of this discovery. The discussion continued. Pietro Molinelli offered a large reward for a gravid eel. In 1777 an eel presenting the same appearance as the one described by Valisneri was sent to Prof. Monti, who, being indisposed for the investigation, gave it over to a set of his favourite pupils, anıong whom was Camillo Galvani. These students pronounced the anatomical appearance to be the same as described by Valisneri, and the specimen was sent to Prof. Mondini for his opinion, which was published in the Bologna Academy's Transac: tions, to the effect that the ovary described by Valisneri was only the swimming bladder in a diseased condition. But in connection with this opinion Mondini gave and illustrated by magnificent plates a good description, and demonstrations of the true ovaries of the eel as found by himself. This classical work of Mondini has been often overlooked. Later, but quite independently of Mondini, the ovary of the eel was discovered by $O$. F. Müller Spallanzani's investigations in 1792 threw doubts upon the discoveries of Mondini and O. F. Müller, so that. when Prof. Rathke in 1824 described the ovaries of the eel as two cuff and collar-shaped organs on both sides of the backbone, he was everywhere in Germany (and is to a large extent to the present day) regarded as the discoverer. The first picture of the ovary, after that of Mondini, and the first plate of the microscopical appearance of the egg of the eel was published in a dissertation by Hohnbaum Hornschuch in 1842 , and the question of the ovary of the cel may be regarded as definitely settled by the publication by Rathke, in 1853 , of a description of a gravid female eel, the first and only specimen of such which had come up to that tine into the hands of an investigator.

The search after the roe in the eel was of much later date. In 1842 and up to 1872 the researches of several observers were unrewarded with success.

Of the various mistakes made in this investigation Dr. Jacoby gives us an interesting account. In the meanwhile the late Dr. Syrski, the Director of the Museum of Natural History at Trieste, had undertaken, at the request of the marine officials at Trieste, to determine t.e spawning. time of the fishes of this region, and he devoted a good deal of his attention to the smaller eels. On November 29,1873 , Dr. Syrski found in an eel, now preserved in the Museum at Trieste, which was fifteen inches long, a completely new organ, which had never before been seen within an eel by any former investigator, although tens of thousands of eels had been zealously studied. Syrski published his discovery in the Proceedings of the Vienna Academy for April, 1874 , and, according to all the researches up to this time made, there would seem the highest probability that this organ of Syrski is actually the long sought, but immature male organ. The investigation cannot be said to be complete until the presence of spermatozoa is determined; but the recent discovery of such in the similar spermaries of the conger eel, by Dr. Hermes, of Berlin, is a strong confirmation. The eels with the Syrskian organ are smaller than the females, and are to be found only in the sea and brackish water. They have a short and sharply-pointed snout. Their dorsal fin is less broad, and not so high as in the females.

This discovery of Syrski drew attention anew to the solution of the eel problem. Among others, the German Fischerei-Verein in Berlin offered a reward of 50 marks to the person who should first find a gravid eel sufficiently developed to satisfy Prof. Virchow of the fact. Herr 
Dallmer, of Schleswig, Inspector of Fisheries in that province, offered to transmit communications to Berlin, and in 1878 he published an interesting report of the proceedings. Quite beyond all his expectations, his wishes had been made known by the press to all the regions between the Rhine and the Weichsel, and from the Alps to the sea. The number of letters which he received at first gratified him, next surprised him, and finally so terrified him, that at last he was obliged to refuse to atter $\mathrm{d}$ to communications. Prof. Virchow also received an incredible amount of letters from all parts of Germany, and in a little time Prof. Virchow too was comfelled to publish a notice urgently requesting no more communications to be sent to him, for that he did not know what to do with those he had got.

Althcugh a few links are still wanting to complete the chain of the life-history of the eel, it may be most safely assumed that the eel lays its eggs like the majority of fishes, and further, that, like the lamprey, it only spawns once and then dies. It would also seem most probable that the spawning takes place only in the sea. Eels placed in land-locked ponds, though they increase in size, never, it is well known, increase in numbers. The most important problem still to be solved is, do the male eels ever leave the sea and enter fresh water. Dr. Jacoby found male eels in the lagoons of Commachio, where the water is brackish, and these must have ascended in the mounting as fry, and then, probably, at the approach of sexual maturity, descended with the females to the sea. Dr. Hermes found some i i per cent. of males among eels taken at Willenberg on the Elbe coast, I2O miles from the German Ccean, and no males whatever at Havelberg, twenty or thirty miles higher up the stream. Thus the numerical percentage of males to females was in proportion to the nearness to the sea.

In connection with this subject the valuable observations of Dr. Hermes on the conger, made during $188 \mathrm{I}$, in the tanks of the Berlin Aquarium, may well be alluded to. Dr. Hermes found the reproductive organ in the conger very similar to those as now supposed to exist in the common eel, and in the comparison of size the relations remain the same. The male congers are much smaller than the females.

Space will not allow us to do more than refer to the journey of Dr. Jacoby in 1877 , from Trieste, by way of Ravenna, to Commachio; nor to his account of the sterile females of a delicious flavour, known as Pasciuti; but we would suggest that no more satisfactory or useful work could be translated than Jacoby's "History of the Eel: with an Account of the Celebrated Eel Fishery of Commachio;" which was issued from the Berlin firm of August Herschwald, not very long ago.

\section{SIR HENRY COLE, K.C.B.}

HENRY COLE, the eldest son of Captain Henry Robert Cole, was born at Bath, on July I 5 , 1808 . On January I2, 18I7, he was admitted to Christ's Hospital, where he remained until April 9, 1823. There had been some idea of sending him into the Church, but it was abandoned, and the day after he left school he commenced his career in the public service, under $\mathrm{Mr}$. Cohen, afterwards Sir Francis Palgrave. His leisure at this time was spent in botanising in the neighbourhood of London; drawing under the tuition of David Cox, and contributing to the public journals. On December 28 , 1833, he married his cousin, Miss Marian Bond. The public records were endangered by the burning of the Houses of Parliament in the following year. Cole worked vigorously for their preservation at the time, and was for long afterwards engaged in their arrangement. In spite of these heavy labours he had found time to commence a work on light, shade, and colour, when the prosperity of the young manager was abruptly interrupted by his sumnary dismissal from the Augmentation Office on December 5, I835. He had ventured to call in question, and that in the singularly emphatic manner which characterised him through life, the competency of his official superiors, and had indicated the gross mismanagement which then obtained. It was believed that Mr. Cole's charges were unfounded, but a Committee of the House of Commons fully justified his action. He was at once reinstated in his office and advanced to be assistant keeper of the Records. At this period of his career he did yeoman's service to the cause of postal reform, and found leisure to issue, under the nom de plume of Felix Summerly, a series of Guide Books to Hampton Court, Canterbury, Westminster Abbey, Temple Church, the National Gallery, Free Picture Galleries, Day Excursions, Holidays spent in and near London, as well as to the various lines of Railway as they sprang into existence. Besides these he published his long-deferred "Light, Shade, and Colour," and it is one of the features of his life that he uniformly dropped a scheme which was for the time abortive, and uniformly took it up again at the relinquished point when a more propitious time arrived. $\mathrm{He}$ also wrote numerous works for the amusement and instruction of children in whose service he enlisted some of the most eminent artists then living. He found employment for ladies in engraving his illustrations, thus making an early attempt to solve the difficult problem of woman's work.

About this time his artistic sensibilities were shocked at the native hideousness of British manufactures, and he became a member of the Society of Arts, into the fossilised bones of which he soon instilled a new vigour. Still it was with the greatest difficulty that the leading manufacturers could be induced to co-operate. A prize competition was projected, but they dreaded to permit their names to appear, so jealous were the retail traders of their own interests. At last the show of Art Manufactures came off, and Henry Cole gained the silver medal of the Society of Arts for his "Felix Summerly" tea service. This success he followed up by a plan for the regeneration of British art applied to industry by the establishment of quinquennial exhibitions of British manufactures to commence in 1851 . He commenced the issue of the Journal of Design to disseminate his views, and to gain information he visited the exhibition held in France in 1849 . On his return he submitted his draft project to Prince Albert, by whom it was favourably received; the design grew, and expanded from a projected national exhibition to be held on the then waste ground of Leicester Square into the Great Exhibition of All Nations in Hyde Park. The conception was novel, and friends were timorous-fights hard and frequent enough to have subdued a less resolute will fell to Cole's lot-but by dint of a bull-dog refusal to be beaten, he ultimately assured the successful issue of the vast undertaking. The results gained by that success surround us on every hand in the improved taste of the country, as well in important as trivial matters. This is apparent when the manufactures of to-day are compared with those endured by our fathers.

At the conclusion of the Exhibition he had the satisfaction to see the purchase of a small collection of objects chiefly from the Indian court. These, with the drawings. from the schools of design, were lodged in Marlborough House as the nucleus of a possible national art repository, which has been since realised in the South Kensington Museum.

Mr. Cole was, in 1852, appointed General Superintendent of the Department of Practical Art, which was succeeded in the following year by the Department of Science and Art, and it devolved upon him to reorganise the desultory instruction which had up to that time been afforded by the Schools of Design. How ably he, with the invaluable assistance of Mr. Richard Redgrave, R.A., 